\title{
Skin lesions caused by bortezomib targeted therapy of multiple myeloma
}

\section{Zmiany skórne wywołane bortezomibem stosowanym w terapii szpiczaka mnogiego}

Inhibition of proteasomes (proteolytic complexes responsible for the degeneration of ubiquitinated proteins) is a promising option in the therapy of hematologic malignancies. Bortezomib is the firstin-class proteasome inhibitor, which has been used in the treatment of multiple myeloma, mantle cell lymphoma and non-Hodgkin lymphoma. Despite the fact that cutaneous adverse reactions caused by bortezomib are quite frequent, they are poorly described in the medical literature [1,2]. To our knowledge, this is the first report in Poland on an adverse cutaneous reaction caused by bortezomib.

A 62-year-old woman was diagnosed with stage I-A IgGк multiple myeloma. The patient was treated with combined chemotherapy (cyclophosphamide, thalidomide and dexamethasone), but remission was not achieved. Therefore, intravenous therapy with bortezomib $\left(1.3 \mathrm{mg} / \mathrm{m}^{2}\right)$ was administered. After the second cycle of bortezomib chemotherapy,

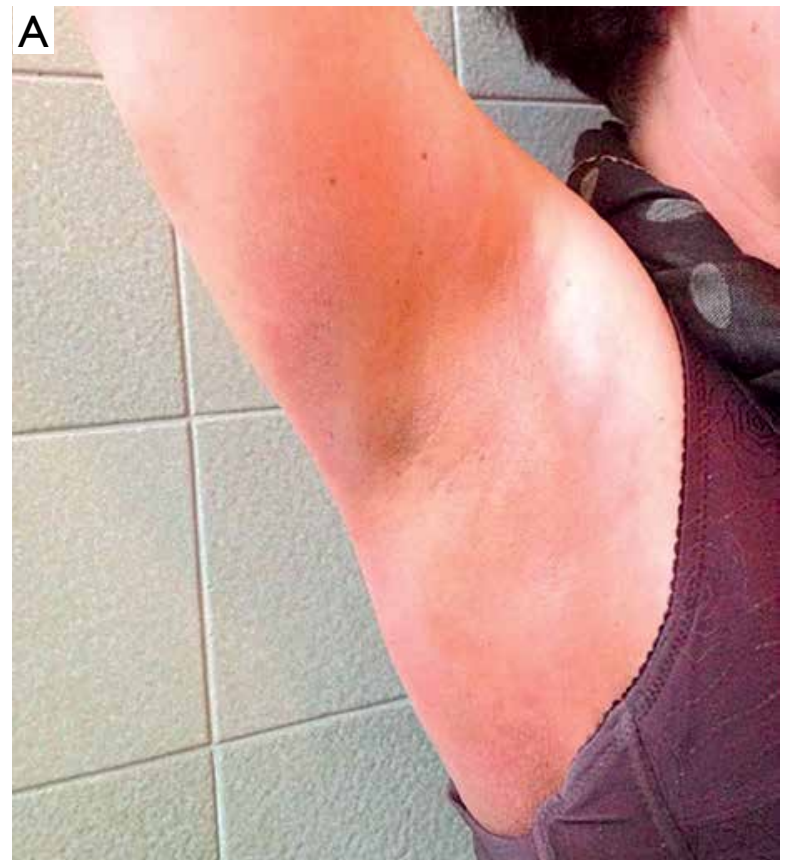

symptoms of polyneuropathy occurred, classified as grade 2 according to Common Terminology Criteria for Adverse Events 4.0 (CTCAE). Therapy was continued with a lower dose of the drug $\left(1 \mathrm{mg} / \mathrm{m}^{2}\right)$. After the third chemotherapy cycle, symmetrical, erythematous lesions with mild scaling and pruritus on the palms and axillary regions (grade 1 according to CTCAE) appeared (Figures 1 A, B). The cutaneous lesions resolved completely after topical treatment with mid-strength glucocorticosteroids and emollients. Similar lesions reappeared again after the fourth cycle of bortezomib chemotherapy, and again topical treatment proved to be successful. Bortezomib was discontinued due to the lack of clinical response of multiple myeloma.

The most common side effects of bortezomib are gastrointestinal symptoms, thrombocytopenia, neutropenia, fatigue and peripheral neuropathy [3]. Adverse cutaneous reactions during the therapy are

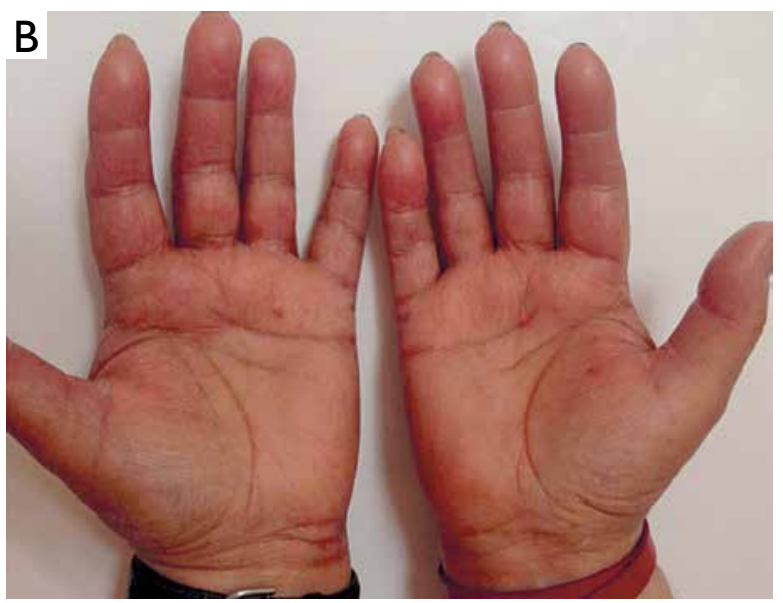

Figure I. Erythematous lesions with mild scaling in axillary $(\mathbf{A})$ and palmar (B) areas

Rycina I. Rumieniowe wykwity z delikatnym złuszczaniem w okolicy pachowej (A) oraz na powierzchni dłoniowej rąk (B) 
observed in $8-24 \%$ of patients $[1,2]$. They are characterized by diversity of the clinical and histopathological presentation. The clinical spectrum of skin lesions described so far includes: different forms of rash (maculopapular, papulonodular, nodular, vasculitic, acneiform, purpuric, "folliculitis-like"), small vessel vasculitis, Sweet syndrome, Sweet-like syndrome, and lupus tumidus. Histopathological features of skin lesions generally show various vasculitis reactions $[2,4,5]$. The response to topical or systemic glucocorticosteroid treatment is usually quick and rewarding. Glucocorticosteroids may also be recommended in between the bortezomib cycles as a prophylaxis of adverse skin reactions.

The pathogenesis of skin involvement is probably related to the increased release of proinflammatory cytokines and the generation of a cell-mediated immune response. Some authors state that development of a rash during bortezomib therapy is correlated with better response to the treatment [6].

In conclusion, bortezomib has considerable potential to induce adverse cutaneous reactions, but the risk of serious or systemic involvement is very low. Most of them are rather mild skin reactions that can be easily managed and do not require withdrawal of the drug. The rise in the use of proteasome inhibitors will probably lead to more frequent cutaneous adverse reactions.

Received: 25 VI 2016

Accepted: 28 IX 2016

\section{References}

1. Richardson P.G., Barlogie B., Berenson J., Singhal S., Jagannath S., Irwin D., et al.: A phase 2 study of bortezomib in relapsed, refractory myeloma. N Engl J Med 2003, 348, 2609-2617.

2. Sanchez-Politta S., Favet L., Kerl K., Dietrich P.Y., Piguet V.: Bortezomib-induced skin eruption. Dermatology 2008, 216, 156-158.

3. Scott K., Hayden P.J., Will A., Wheatley K., Coyne I.: Bortezomib for the treatment of multiple myeloma. Cochrane Database Syst Rev 2016, 4, CD010816.

4. Truchuelo M., Bagazgoitia L., Alcántara J., Velasco D., Carrillo R.: Sweet-like lesions induced by bortezomib: a review of the literature and a report of 2 cases. Actas Dermosifiliogr 2012, 103, 829-831.

5. Garcia-Navarro X., Puig L., Fernández-Figueras M.T., Dalmau J., Roe E., Alomar A.: Bortezomib-associated cutaneous vasculitis. Br J Dermatol 2007, 157, 799-801.

6. Gerecitano J., Goy A., Wright J., MacGregor-Cortelli B., Neylon E., Gonen M., et al.: Drug-induced cutaneous vasculitis in patients with non-Hodgkin lymphoma treated with the novel proteasome inhibitor bortezomib: a possible surrogate marker of response? Br J Haematol 2006, 134, 391-398.

Michał Sobjanek ${ }^{1}$, Martyna Sławińska ${ }^{1}$, Anna Starzyńska ${ }^{2}$, Małgorzata Sokołowska-Wojdyło ${ }^{1}$

${ }^{1}$ Department of Dermatology, Venerology and Allergology, Medical University of Gdansk, Gdansk, Poland ${ }^{2}$ Department of Maxillofacial and Oral Surgery, Medical University of Gdansk, Gdansk, Poland 